\title{
Novel integrated acid gas removal and forward osmosis draw solution regeneration system for saving energy and water treatment
}

\author{
Abdukarem Amhamed, Ahmed Abotaleb \\ Hamad Bin Khalifa University (HBKU), Qatar Environment \& Energy Research institute (QEERI), Qatar Foundation, P.O. Box 34I I0 Doha, Qatar
}

Correspondence: Dr. Abdukarem Amhamed, Hamad Bin Khalifa University (HBKU), Qatar Environment \& Energy Research institute (QEERI), Qatar Foundation, P.O. Box 34II0 Doha, Qatar, Email aamhamed@hbku.edu.qa

Received: September II, 2018 | Published: September 28, 2018

Copyright@ 2018 Amhamed et al. This is an open access article distributed under the terms of the Creative Commons Attribution License, which permits unrestricted use distribution, and reproduction in any medium, provided the original author and source are credited.

\begin{abstract}
Chemical absorption is the most common technology used in the Acid Gas Removal (AGR) systems for treating sour gases, but suffers from high regeneration energy and co-process produced water. Co-process produced water is often considered a waste by-product, but recently the industry is beginning to exploit it as a potential profit.

In this study, a novel integrated AGR and Forward Osmosis (FO) regeneration system is proposed to reduce the energy consumption in both systems, as well as treating the wastewater from the AGR units. This process utilizes ethanol as a draw solution (DS) along with n-pentane as a low boiling point agent for facilitating the separation of ethanol-water mixture at low temperature. $\mathrm{N}$-pentane is the cross component between the AGR \& FO units, through a new economizer coolant fluid replacing the circulated lean amine conventional cooling equipment "air cooler and trim cooler".
\end{abstract}

\section{Introduction}

Natural gas (NG) is a crucial factor in the world's supply of energy for industrial and domestic utilization. ${ }^{1}$ The harsh drive to improve energy efficiency is causing global energy consumption to slow down. In addition, the innovation and energy mix is shifting in the direction of lower pollutants and less cost driven by environmental needs and process technological advances. ${ }^{2}$

NG is the cleanest source of fossil fuel, while the cleanest energy source is the geothermal energy. ${ }^{3}$ It is extracted from oil and gas reservoirs as a mixture of light hydrocarbons and other impurities including sour gases, mercaptans, water, and mercury. ${ }^{4}$ It is a combustible mixture of hydrocarbon gases, and its composition may vary widely. It is referred to as a sour gas when several contaminants such as $\mathrm{H}_{2} \mathrm{~S}$ and $\mathrm{CO}_{2}$ are present. Moreover, $\mathrm{CO}_{2}$ is providing no heating values, ${ }^{2}$ considered as a major greenhouse gas that causes global warming and lowering the performance of several industrial processes in the oil and gas sector. ${ }^{5}$ In addition to $\mathrm{CO}_{2}$ and $\mathrm{H}_{2} \mathrm{~S}$, natural gas may contain other contaminants such as carbonyl sulfide (COS), mercaptans (R-SH), and carbon disulfide $\left(\mathrm{CS}_{2}\right){ }^{6,7}$

Downstream processing units, such as NGL, LNG, GTL and petrochemical plants could be dramatically affected by improper removal of sour gases. Chemical and physical solvents absorption process are commonly used for acid gas removal. ${ }^{8,9}$ Most of the current AGR units operation are based on the absorption/desorption process with a solution of methyldiethanolamine (MDEA) 40 to 50
This work has been developed using Aspen HYSYS V8.8 amine package along with CPA package for FO-DS regeneration. The results show that, this proposal could save $15 \%$ of new AGR plants capital cost (Capex) due to eliminating the lean amine air cooler, trim cooler, reduce electrical consumption by more than $20 \%$ for new and existing plants. The net capex savings for the new AGR unit is $\$ 9687 /$ MMSCFD, while added capex for existing units is $\$ 6504 /$ MMSCFD. In addition, a $93.6 \%$ by wt. diluted draw solution could be recovered as a treated water. This proposal is promising for retrofitting an existing AGR process and desalination (FO) units.

\section{Keywords}

Acid Gas Removal, Forward Osmosis, process integration, regeneration, n-pentane, ethanol

wt.\% in water. AGR systems suffer from several drawbacks, and the most critical is the large amounts of energy required for regeneration of the rich amine, which is equivalent to 60 to $70 \%$ of the total operating cost of the AGR system. ${ }^{10,11}$ Therefore, the high regeneration consumption has to be addressed as a critical issue in the current AGR system. As an example, the energy consumption in an amine system using (MEA) was reported to be about 4.2-4.4 GJ/tone $\mathrm{CO}_{2}$ removed, ${ }^{7}$ while in piperazine and some developed scrubbing amine systems, the required heat is $2.6 \mathrm{GJ} /$ tone $\mathrm{CO}_{2}{ }^{9}$

Several attempts have been conducted in AGR systems to reduce the energy consumption and enhancing the performance of sour gas loading. ${ }^{11}$ Rochelle et al. ${ }^{12}$ used the intercooling concept in the packed absorber to avoid the negative effects of high absorber temperature. A detailed study was conducted by Abotaleb et al.. ${ }^{10}$ for enhancing the acid loading by manipulating the amine system.

On the other hand, co-produced water is a waste by-product that is produced during gas extraction operations and processing. It is estimated that the oil and gas sector produces about 14 billion bbl. of water annually. ${ }^{13,14}$ The quality and quantity of co-produced water vary greatly and in some cases, the water can be a valuable by-product and a useful commodity.

Recently, the Oil and Gas industry is beginning to consider co-process produced water as a potential profit stream if treated in an efficient way with a low cost. The co-process produced water usually comprises of organic, inorganic compounds and suspended particles (Table 1).
Submit your Article | www.ologypress.com/submit-article OP Ology $f$ in $y$ (intio
Citation: Amhamed A, Abotaleb A. Novel integrated acid gas removal and forward osmosis draw solution regeneration system for saving energy and water treatment. J Oil Gas Petrochem Sci. (20I8); (3):9I-99. DOI: 10.30881 /jogps.000I7 
Moreover, it contains all the added chemicals during the production process such as anti-scaling and anti-corrosion. The volume of coproduced water and their impurities strength typically vary from one well to another over the oil and gas fields' lifetime. Typically, the co-process produced water from gas fields is enriched with minor molecular hydrocarbons such as benzene, toluene, ethylbenzene, xylene, and heavy metals. . $^{15,16}$

Table I Typical produced water measurements in Qatar. ${ }^{47}$

\begin{tabular}{|c|c|c|}
\hline Component name & Method & $\begin{array}{l}\text { Concentration } \\
(\mathrm{mg} / \mathrm{L})\end{array}$ \\
\hline Calcium & API 45 (1968) & 17240 \\
\hline Magnesium & API RP 45 (1968) & 3315 \\
\hline Sodium & APHA $311 I$ & 66219 \\
\hline Potassium & APHA 3111 & 3370 \\
\hline Silica & APHA $311 I$ & 67 \\
\hline Soluble iron & APHA 3111 & 0.9 \\
\hline Total iron & APHA 3111 & 1 \\
\hline Boron & APHA 4500 B & 15.4 \\
\hline Barium & APHA $311 I$ & 30 \\
\hline Strontium & APHA $311 I$ & 1560 \\
\hline Copper & APHA $311 I$ & $<0.01$ \\
\hline Nickel & APHA $311 I$ & $<0.01$ \\
\hline Zinc & APHA 3111 & $<0.01$ \\
\hline Cobalt & APHA $311 I$ & $<0.01$ \\
\hline Chromium & APHA 3111 & 0.02 \\
\hline Aluminum & APHA $311 I$ & $<0.01$ \\
\hline Lead & APHA $311 I$ & $<0.01$ \\
\hline Manganese & APHA 3111 & 0.24 \\
\hline Cadmium & APHA 3111 & $<0.01$ \\
\hline Cyanide & APHA 3111 & $<0.001$ \\
\hline Selenium & APHA 3111 & $<0.001$ \\
\hline Arsenic & APHA 3111 & $<0.001$ \\
\hline Mercury & APHA 3111 & $<0.0001$ \\
\hline Ammoniacal nitrogen & APHA $4500 \mathrm{NH} 3$ & 1.2 \\
\hline Total phosphates as $\mathrm{p}$ & APHA 4500 P D & 0.2 \\
\hline Chlorides & APHA $4500 \mathrm{Cl}-\mathrm{B}$ & 139310 \\
\hline Sulphates & APHA 4500 SO4 2-C & 560 \\
\hline Sulfides & APHA 4500 S- & 7 \\
\hline Carbonates & APHA 2320 B & 0 \\
\hline Bicarbonates & APHA 2320 B & 248 \\
\hline Free $\mathrm{CO}_{2}$ & APHA $4500 \mathrm{CO} 2 \mathrm{C}$ & 128 \\
\hline Salinity as $\mathrm{NaCl}$ & Calculation & 229860 \\
\hline $\begin{array}{l}\text { Total oil content ppm } \\
\text { range }\end{array}$ & Historical & $5.4 \times 104-39$ \\
\hline $\begin{array}{l}\text { Total dissolved solids at } \\
105^{\circ} \mathrm{C}\end{array}$ & APHA 2540 B & 232020 \\
\hline Total hardness as $\mathrm{CaCO}_{3}$ & APHA 2340 B & 57530 \\
\hline
\end{tabular}

The co-produced water needs to meet the quality required, before it can be used for oil and gas operation activities, such as drilling, stimulation and workover activities. Furthermore, in some cases significant treatment of produced water is required to meet the quality for irrigation or animal consumption purpose especially if there is harmful light hydrocarbons. ${ }^{17}$ The most amount of water available (about 97\%) is low quality water or seawater, ${ }^{18}$ which needs to be purified and treated in an efficient way. Desalination is a reliable process to remove salts from seawater. Several techniques have been used for water desalination in most are thermally based techniques. ${ }^{19}$ Therefore, they are consuming high energy per water desalinating volume. ${ }^{20}$ In addition to the limitation of fresh water resources, the demand for clean water has been increasing dramatically due to population growth, agriculture and industrials requirements. ${ }^{20}$ Recently advanced technologies, which is membrane based desalination methods, such as reverse osmosis RO have been widely used as alternative techniques for water desalination due to the relatively low cost compared to thermal methods. ${ }^{21}$

In RO technology, a high-applied pressure is required to push the low quality water through the membrane. Therefore, a high power consumption as well as high strength material to overcome the high pressure is unavoidable, which leads to a high operational cost. ${ }^{22}$ Additionally, RO is a relatively low water recovery which is about 35$50 \%$ from seawater feed ${ }^{23}$ and produced concentrated brine makes the RO process limited due to the environmental issues. Accordingly, it is understandable that the development of a low energy consumption desalination process is significantly desirable to make the membrane technologies more competitive and attractive compared to other desalination methods. To obtain that, the present novel process technology is suggested. It is integrating the FO and AGR units in a closed cycle system using a low energy technique for FO agent regeneration. The AGR unit is used to provide a source of heat for FO DS regeneration unit. On the other hand, FO is used to drive fresh water naturally from low salt concentration side towards high salt concentration side.

FO system, which is also known as natural osmosis, utilizes a dense membrane to separate two solutions with different chemical potential (concentrations). The process simply deals with the permeation of water from a feed solution of high chemical potential or low osmotic pressure, through a semipermeable FO membrane to a DS of low chemical potential or high osmotic pressure. The FO membrane works as a barrier to pollutants, dissolved organic matters and suspended solids. ${ }^{16}$ In this system, the water from the low concentrated solution migrates naturally to the high concentrated solution because of the osmotic pressure gradient, ${ }^{16}$ which eliminates the need for highapplied hydraulic pressure as well as the fouling compared to the RO. In fact, the development of fouling on the FO membrane surface is easily removed by simple hydraulic washing. Furthermore, the FO system has the capability of removing all the suspended particles and almost all the dissolved elements. ${ }^{16}$

Recently, the FO system has been used to treat the co-process water from the drilling mud waste and has been able to recover more than $80 \%$ of the water. ${ }^{16}$ Although FO has a high rejection rate for most of the organic and inorganic impurities, its applications still have some critical constraints related to the diluted draw solution regeneration process. Several attempts have been conducted for applying different techniques to recover draw solutions, like air stripping, ${ }^{24}$ heating, ${ }^{25}$ distillation, ${ }^{26}$ chemical reaction, ${ }^{27}$ Reverse Osmosis, ${ }^{28}$ and Moderate heating (about $60^{\circ} \mathrm{C}$ )..$^{24,28,29}$ The obtained results showed that, most of these methods consumed high energy or hydraulic pressure. It's worth mentioning that, other novel methods have been proposed for low regeneration energy consumption. ${ }^{30-35}$ Therefore, finding the optimum DS regeneration technique is one of the main challenges for the future of FO desalination.
Submit your Article | www.ologypress.com/submit-article

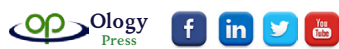


The driving force in FO system is the difference in osmotic energy potential generated by osmotic agent. Hence, the osmotic agent has to be a high osmotic pressure in addition to other properties. ${ }^{36}$ Alcoholic-water solution has a high osmotic pressure with a relatively low alcoholic/ water mole ratio, which generates a high permeated or fresh water flux across a membrane by natural osmosis. ${ }^{37}$ Ethanol can be used as a draw solution due its lower enthalpy of vaporization $42.32 \mathrm{~kJ} / \mathrm{mol}$, compared to water $43.99 \mathrm{~kJ} / \mathrm{mol}$ at $298.15 \mathrm{~K}$ in addition to its lower boiling point at atmospheric pressure compared to water. ${ }^{38}$ Those two factors facilitates a separation process between the ethanol and water in case of using existing aqueous-dehydration technique of ethanol separation technologies such as the pervaporation, distillation or adsorption to re-concentrate the draw solution. ${ }^{22}$

The separation of ethanol-water mixture is energy intensive, especially when ethanol concentration is lower than $5 \%$ by weight. ${ }^{39}$ For this reason, a low energy consumption process is suggested to regenerate the agent that is diluted through the FO process. This process is based on adding a light hydrocarbon such as n-pentane or iso-pentane to the diluted stream formed from draw solution through the principle of direct contact, vapor-liquid heat and mass transfer. The proposed system provides a great ease of separation between the ethanol and water compared to the conventional separation processes. The ultimate aim of this study is to develop a novel AGR-FO integrated system with minimal modifications to reduce the energy consumption in both systems: the AGR and FO regeneration unit.

\section{Methodology}

\section{Problem definition}

The specific problem that this invention solves is reducing the acid gas removal plants energy consumption and treating the saline water or wastewater produced in field. In fact, cooling the circulated lean amine is one of the critical steps in the acid gas removal system as the $\mathrm{CO}_{2}$ absorption is favoring low temperature operation. Usually air coolers are used to cool lean amine, and then lean amine is further cooled by trim cooler driven by cold water. In desert regions like Middle Eastern, the efficiency of air coolers and cooling towers dramatically decreases at summer time due to the harsh climatic conditions; $100 \%$ humidity and $50^{\circ} \mathrm{C}$ ambient temperature. Moreover, some plants have no access to any source of water due to demographic location.

In addition, produced water (PW) is the largest waste stream generated in oil and gas industries; it contains a mixture of different organic and inorganic components, discharging produced water will pollute surface, underground water and soil. Therefore, one of the key challenges facing the gas industry is to find an economic way to reuse the produced and wastewater from acid gas removal systems in Natural Gas Liquefied plant (NGL), Gas recycling plants (GRP), and Refineries.

Therefore, FO is proposed to treat the co-processed water from NGL through utilizing the lean amine stream temperature for draw solution regeneration. FO commonly recognized as an energy independent process. However, its theoretical energy free mechanism, limited viable applications have been implemented for FO based desalination. The main challenges in the FO process are the development of new membranes in suitable configuration, the deficiency of extraction process of the treated-water from draw solution (DS) and the costeffectiveness of the DS regeneration process.

Low molecular weight alcohols, such as ethanol $(\mathrm{EtOH})$ is proposed in this case which may be useful as draw agents in the FO desalination process. This is due to the high osmotic pressures that may be obtained at an acceptable level of concentration. However, the separation of alcohol from water may be the critical step in the process due to the extent of energy required. Hence, utilizing a low energy-consumption regeneration process could improve the FO process application. Many processes for Ethanol separation were used such as extraction distillation with various solvents and separating agents, heterogeneous azeotrope distillation with different solvents such as pentene, benzene and cyclohexane and adsorption with molecular sieves. ${ }^{40,41}$

The separation of ethanol-water mixture is energy intensive especially when ethanol concentration is lower than $5 \%$ by weight. ${ }^{39}$ The first step in ethanol-water separation process is using the distillation column, which can produce ethanol at concentration near to the azoetropic concentration about $95 \%$ by weight ethanol. The separation process, however, above this concentration becomes very complicated and high-energy consumption. Nevertheless, the ethanol-water separation utilizing thermal distillation technique is uneconomical and not viable in case of desalination due to the large energy requirement and the reduction of its efficiency at low ethanol concentration. Therefore, the separation process could be achieved through different steps: ethanol separating up to certain concentration, then further dehydration which required more complicated techniques such as extractive distillation, liquid-liquid extraction or membrane distillation, molecular sieves and flash distillation under pressure reduction..$^{40} \mathrm{~A}$ low energy separation technique utilizing heating and cooling direct contact heat transfer concept was suggested. ${ }^{42}$ The process is based on the principle of energy recovery utilizing low grade heat of temperature in the range $\left(20-40^{\circ} \mathrm{C}\right)$. Since, most energy consumed during the separation of ethanol-water mixture; an efficient energy recovery approach would reduce the net energy consumption in the whole process to an optimal level.

Recently, a low boiling point light hydrocarbon immiscible in water is used to allow the separation of ethanol-water mixture at low temperature. Different light hydrocarbons could be implemented, such as n-pentane, iso-pentane and neo-pentane and other. While all they are nearly completely immiscible with water and in the same time completely miscible with ethanol, the main difference among them is the boiling point range. The boiling points of $n$-pentane, iso-pentane and neo-pentane are 36,28 and $10^{\circ} \mathrm{C}$, respectively. This low range of boiling point provides an opportunity to implement this technique at different climatic conditions around the world.

\section{Process Description}

\section{Conventional acid gas removal process scheme}

In benchmark AGR Plants (Figure 1), the sour gas is fed to a knock out drum where the heavy HCs, droplets of water, slugs and any matter of solid is precipitated and then the sour gas is contacted counter currently with amine solvent in a tray or packed columns. The required amine concentration and flow rate are selected according to the sour gas compositions, flow rate and required treated gas quality. The treated gas exists the contactor from top while the amine solvent with acid gases "rich amine" from bottom. As a rule of thumb, the acid gas contactor is favoring the high pressure and low temperature while the regenerator tower is the reverse. Therefore, the rich amine is heated up before entering the regenerator by exchanging with recycled lean amine from stripper. In stripper by using low-pressure saturated steam as a heating source, the acid gases are stripped from amine solvent while the regenerated amine solvent is recycled back to contactor. Before entering the contactor, lean amine shall be cooled
Submit your Article | www. ologypress.com/submit-article OP $\underset{\text { Press }}{\text { Ology in } y \text { rite }}$ 
from $\left(125^{\circ} \mathrm{C}\right)$ to reach the required temperature $\left(52^{\circ} \mathrm{C}\right)$ to enhance acid gas absorption; it is first exchanged with rich amine in interchanger then cooled by air coolers and finally by trim cooler driven by cooled water.

\section{Conventional forward osmosis process scheme}

In Forward Osmosis (FO) Desalination Process (Figure 2), the contaminated water is fed to the osmosis FO unit after some pretreatment. The draw solution DS Ethanol (EtOH) aqueous solution is fed to the osmosis unit side. Due to osmosis, pure water moves from low quality (contaminated water) side towards the DS side through the semi-permeable membrane (FO). This is achieved mainly by the osmotic pressure difference between the two fluids on both sides of the membrane. Accordingly, an increase in the fluid volume due to water flux through the membrane dilutes the DS, where a further technique is needed to separate the draw solution from the fresh water for desalination application. Thermal regeneration process of the diluted DS is the most common, reliable and efficient method and accordingly it has chosen here. However, it is the bottleneck of the whole process as most of the FO process energy consumption occurs at the regeneration step, which needs to be optimized.

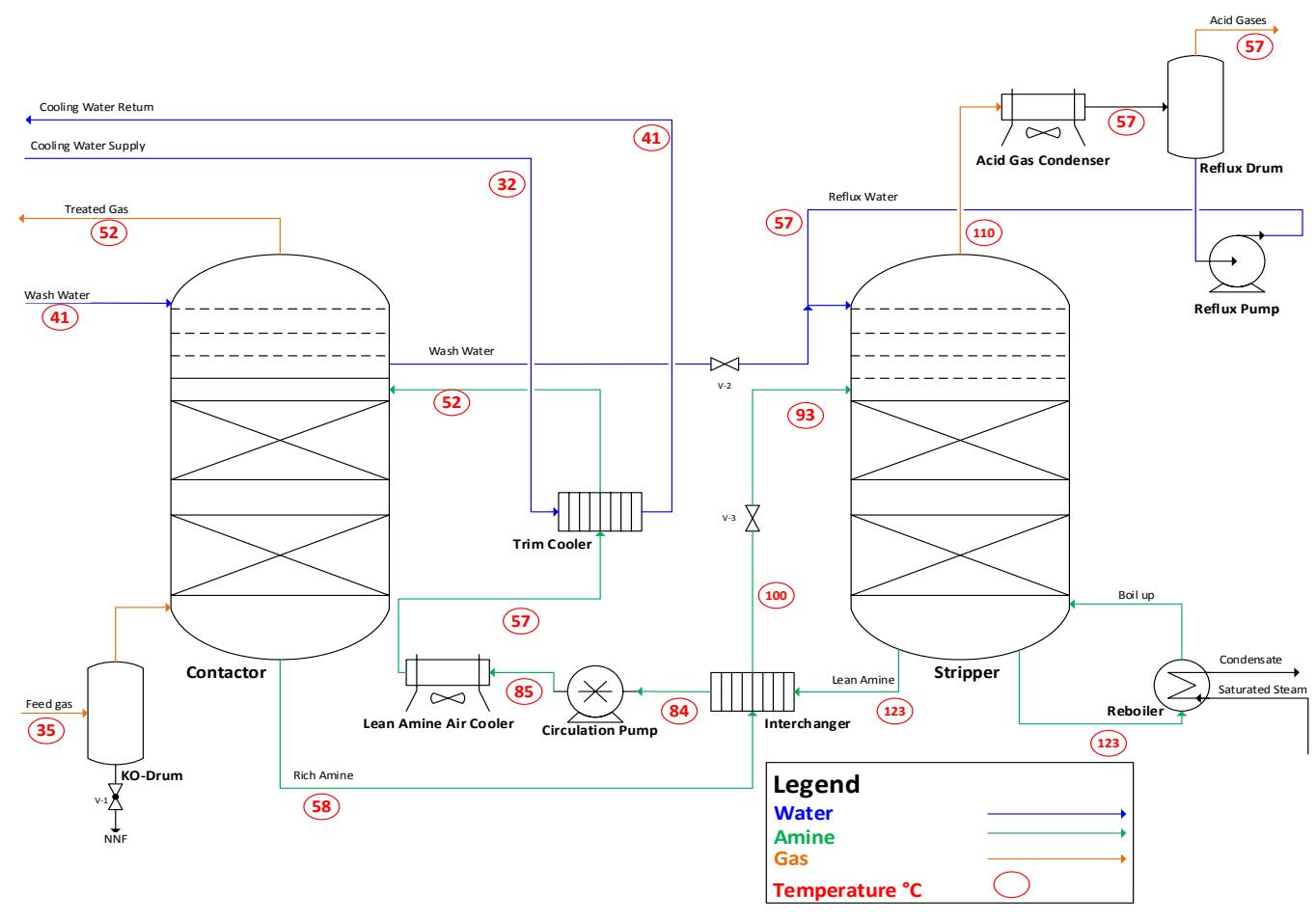

Figure I Conventional acid gas removal schematic process flow diagram.

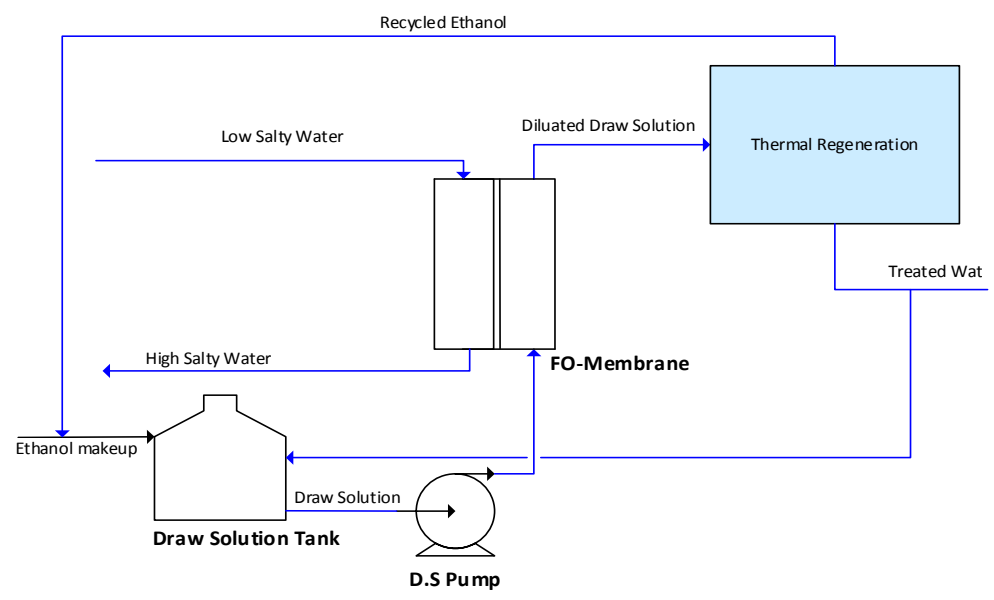

Figure 2 Conventional draw solution regeneration process. 


\section{Design basis}

Aspen HYSYS V8.8 was utilized for simulating the acid gas removal and FO draw solution regeneration sections, where for the AGR section the Electrolyte Non-Random Two- Liquid (Electrolyte NRTL) fluid package was used for electrolyte thermodynamics and Peng Robinson Equation of State for vapor phase properties. The AspenTech's proprietary Rate-Based technology has been used to model the absorber and stripper by calculating the non-equilibrium rate based efficiency for $\mathrm{CO}_{2}$ and $\mathrm{H}_{2} \mathrm{~S}$ at each stage. ${ }^{43}$ The composition and conditions of the sour gas used in the simulation are presented in (Table 2). These were based on real field conditions obtained from Qatar petroleum's acid gas removal unit at the Mesaieed NGL plant. ${ }^{44}$ The benchmark MDEA/PZ (29/1) wt.\% has been used as the amine solvent. The acid gas loading is around 0.48 . The detailed simulation design parameters (equipment dimensions, energy and utility consumption and assumptions) have been taken from Abotaleb et al. ${ }^{10}$

Table 2 Feed gas specifications

\begin{tabular}{lll}
\hline Item & Value & Unit \\
\hline $\mathrm{CO}_{2}$ & 2.391 & Mol\% \\
$\mathrm{H}_{2} \mathrm{~S}$ & 0.924 & Mol\% \\
\hline Temperature & 35 & ${ }^{\circ} \mathrm{C}$ \\
\hline
\end{tabular}

In the FO draw solution regeneration section the Direct-Contact Heat Transfer (DCHT) technique has been developed by introducing a direct contact absorber column driven by low boiling point hydrocarbon (n-pentane) to regenerate draw solution by recycling ethanol and producing treated water. This numerical experiment has been conducted by using Aspen HYSYS v.8.8 process simulation tool with cubic plus association (CPA) fluid package.

\section{Integrated AGR-FO}

This integrated novel system is proposing to use light low boiling point hydrocarbons (n-pentane or iso-pentane), new direct contact absorber and new economizer (plate-plate Heat exchanger), where n-pentane is the cross component between AGR \& FO plants. N-pentane is used to reduce acid gas removal plants energy consumption and ensuring smooth operation by replacing the circulated lean amine conventional cooling equipment "air cooler and trim cooler" with a new economizer (Figure 3), where n-pentane is used as the economizer coolant fluid. It is fed from the pentane tank as a vapor at $\left(34^{\circ} \mathrm{C}\right)$ and slight positive pressure to cool lean amine after interchanger from $\left(84^{\circ} \mathrm{C}\right)$ to the optimum lean amine temperature $\left(52^{\circ} \mathrm{C}\right)$ before entering acid gas contactor to enhance acid gas absorption. The heated pentane $\left(75^{\circ} \mathrm{C}\right)$ is then transferred to water treatment plant "low-energy osmotically driven Forward Osmosis (FO)" specifically the draw solution separation section by absorbing ethanol from the diluted draw solution in a new direct contact absorber to produce high quality treated water.

The new absorber column has ten theoretical stages where n-pentane is entering from bottom and diluted draw solution from $\mathrm{FO}$ to absorber top space at $25-30^{\circ} \mathrm{C}$ in a liquid state. Absorber bottom product is pure water with ethanol concentration less than $3.5 \mathrm{E}-06 \mathrm{ppm}$, wt. and nil pentane while the top product is a mix between n-pentane and ethanol with ethanol concentration less than $2.8 \% \mathrm{wt}$. furthermore, the ethanol will be recycled to draw solution tank and n-pentane to pentane tank. Part of treated water recycled to draw solution tank and split stream will be used as a makeup wash water in AGR contactor to prevent amine carryover, while the remaining part can be utilized as per plant need.

\section{Results and discussions}

By this process-integrated proposal, two equipment in AGR plant could be eliminated; Lean amine air cooler and trim cooler which save $15 \%$ from new AGR plants Capex, reduce electrical consumption by more than $20 \%$ for new and existing plants. Moreover, it overcame the operation fluctuation in summer time for air coolers and cooling towers due to harsh climatic condition in hot regions such as Middle East, North Africa, South America, etc. Furthermore, the need for cooling water supply in AGR plant could be permanently eliminated. In addition, we could save water loss due to evaporation in cooling tower, which is around 3\% from trim cooler water return. On the other hand, high quality water could be produced in AGR plant. In fact, this novel regeneration process can be considered as minimal thermal energy consumption, thus this separation technique can be considered a self-sustainable FO low temperature regeneration.

\section{Mass and heat balances}

A thorough study has been conducted to ensure an efficient separation by finding the optimum $\mathrm{n}$-pentane to diluted draw solution mass ratio. The study started from the mass ratio ranging from 1:1 to $10: 1$ n-pentane to diluted draw solution. It was found that, to completely absorb all ethanol from water, the n-pentane ratio must be higher than 3.76. Moreover, increasing the pentane ratio higher than 4:1 have no significant change on the ethanol separation process. That is why; the optimum mass ratio is $4: 1$ as shown in (Table 3 ). It is worth mentioning that, this ratio could be different depending on the ethanol concentration in the diluted draw solution and the hydrocarbon phase and type.

Table 3 Summary of process parameters

\begin{tabular}{|c|c|c|c|c|c|c|c|c|c|c|c|c|}
\hline \multicolumn{4}{|c|}{ Process Efficiency Parameters } & \multicolumn{3}{|c|}{ Mass Balances } & \multicolumn{2}{|c|}{ Temperature } & \multicolumn{2}{|c|}{$\begin{array}{l}\text { Specific Energy } \\
\text { Consumption }\end{array}$} & \multicolumn{2}{|c|}{ Specific Energy Saving } \\
\hline $\begin{array}{l}\text { Treated } \\
\text { Water } \\
\text { Recovery } \\
\text { (\%) }\end{array}$ & $\begin{array}{l}\text { Ethanol } \\
\text { Conc in } \\
\text { Treated } \\
\text { Water } \\
\text { (ppm,wt) }\end{array}$ & $\begin{array}{l}\text { Ethanol } \\
\text { Fraction } \\
\text { in } \\
\text { mixture } \\
\text { (Mass \%) }\end{array}$ & $\begin{array}{l}\text { Acid } \\
\text { Gas } \\
\text { Loading }\end{array}$ & $\begin{array}{l}\mathrm{kg} \\
\mathrm{n} \text {-Pentane } \\
\text { per kg } \\
\text { Draw } \\
\text { Solution }\end{array}$ & $\begin{array}{l}\text { kg } \\
\text { n-Pentane } \\
\text { per kg } \\
\text { Circulated } \\
\text { Amine }\end{array}$ & $\begin{array}{l}\text { kg Draw } \\
\text { Solution } \\
\text { per kg } \\
\text { Circulated } \\
\text { Amine }\end{array}$ & $\begin{array}{l}\text { Treated } \\
\text { Water } \\
\left({ }^{\circ} \mathrm{C}\right)\end{array}$ & $\begin{array}{l}\text { Ethanol } \\
\text { Top } \\
\text { Product } \\
\left({ }^{\circ} \mathrm{C}\right)\end{array}$ & $\begin{array}{l}\text { kg Cooling } \\
\text { Water per } \\
\text { kg Treated } \\
\text { Water }\end{array}$ & $\begin{array}{l}\text { kg Steam } \\
\text { Reboiler } \\
\text { per kg } \\
\text { Treated } \\
\text { Water }\end{array}$ & $\begin{array}{l}\text { kg Cooling } \\
\text { Water } \\
\text { per kg } \\
\text { Circulated } \\
\text { Amine }\end{array}$ & $\begin{array}{l}(\mathrm{Kwh}) \\
\text { per kg } \\
\text { Circulated } \\
\text { Amine }\end{array}$ \\
\hline $93.63 \%$ & $3.50 \mathrm{E}-06$ & $2.841 \%$ & 0.48 & 4 & 1.58 & 0.39 & 45 & 33.82 & 0 & 0 & 0.51 & 0.024 \\
\hline
\end{tabular}

Furthermore, the ethanol as a draw solution is highly soluble in water, but it is immiscible in water when mixed with light hydrocarbons such as n-pentane, iso-pentane and neo-pentane. Therefore, it is possible to exploit this property to extract the ethanol from water without adding any heat in a direct contact absorber column. However, the mechanism is based on the competition between water and hydrocarbon (n-pentane or iso-pentane) to bond with the ethanol. The high mass of n-pentane in comparison with water content in the diluted draw solution increases the probability to form n-pentane-ethanol mixture, leaving aqueous solution with very low ethanol concentration as the
Submit your Article | www.ologypress.com/submit-article PP ${ }_{\text {Press }}^{\text {Ology } f \text { in } y \text { ritio }}$ 
absorber bottom product. Moreover, the immiscibility of n-pentane in water aids the water gravity separation.

On the other hand, in the new economizer, the mass ratio between the n-pentane to circulated amine is $1.58: 1$ with $9^{\circ} \mathrm{C}$ minimum temperature approach. Accordingly, the mass ratio between diluted DS to circulated amine has been calculated as 0.39:1 (Table 3). A 93.6\% by wt. of absorber inlet diluted draw solution could be recovered as a bottom product "Treated Water" with ethanol concentration less than 3.5E-06 ppm, wt. and nil pentane. The obtained results show that, the top product is a mixture between n-pentane, ethanol and water with weight composition $95.82 \%, 2.84 \%$ and $1.34 \%$, respectively, which is recycled back to pentane tank. Indeed, ethanol will be accumulated and a purge stream will be taken from the recycled pentane-ethanol mixture and accordingly, ethanol make up will added to the draw solution tank (Figure 2).
Furthermore, the thermal energy consumption in FO regeneration section is almost zero as it is a self-sustainable regeneration system due to the low-grade heat provided by the AGR plant instead of utilizing the steam re-boiler. The temperature of each stream is reflected in (Figure 3). Moreover, a temperature profile comparison between the proposed novel FO low temperature heat regeneration system and the conventional FO regeneration system "Distillation column" is shown in (Figure 4), where the absorber top product recorded $33.8^{\circ} \mathrm{C}$ and bottom product at $45^{\circ} \mathrm{C}$, while in the conventional system is $79^{\circ} \mathrm{C}$ and $102.6^{\circ} \mathrm{C}$, respectively. Notably, the huge difference between the temperature profile in the proposed novel system and the conventional one is the result of the technology applied. The conventional method uses distillation column integrated with condenser and reboiler, while the novel proposes an absorber column. In fact, the top and bottom tray temperatures in the absorber column are much lower than that in the distillation column due to the entrainer (n-pentane) effect.

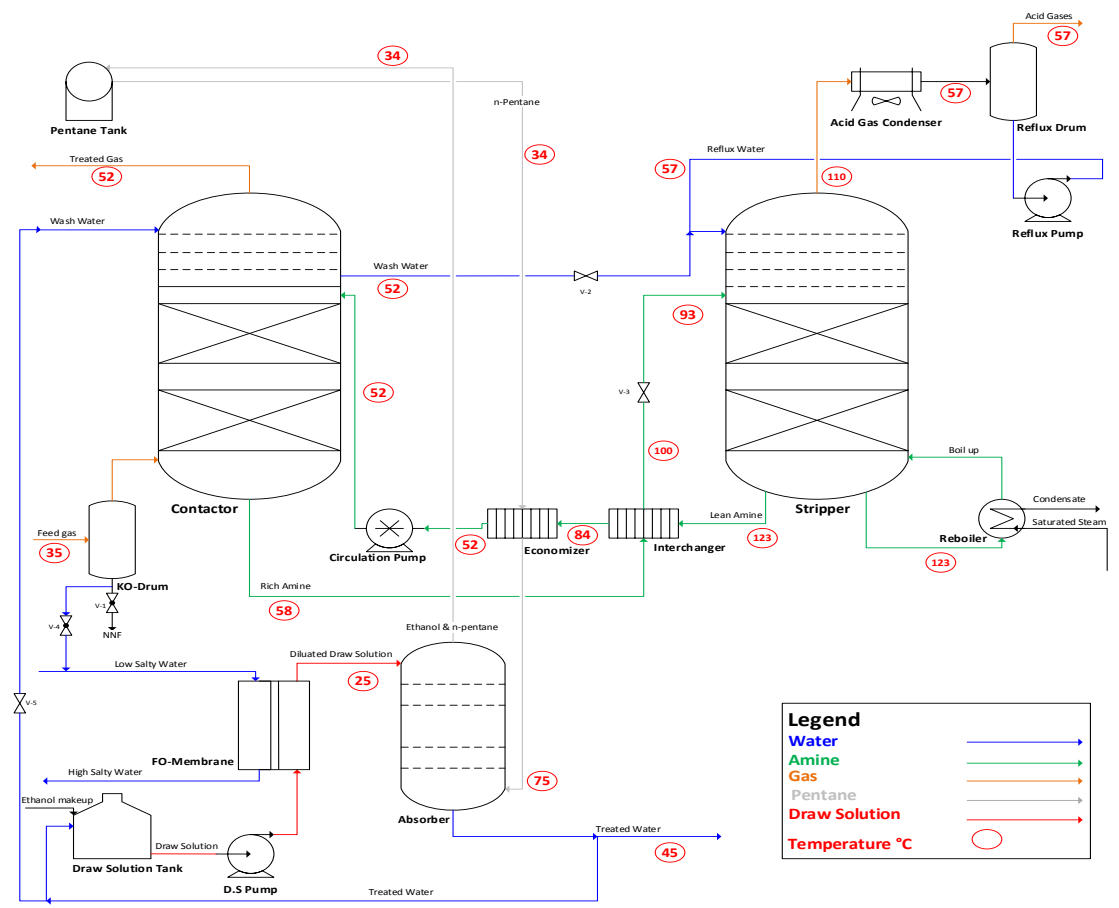

Figure 3 Hybrid AGR-FO schematic process flow diagram.

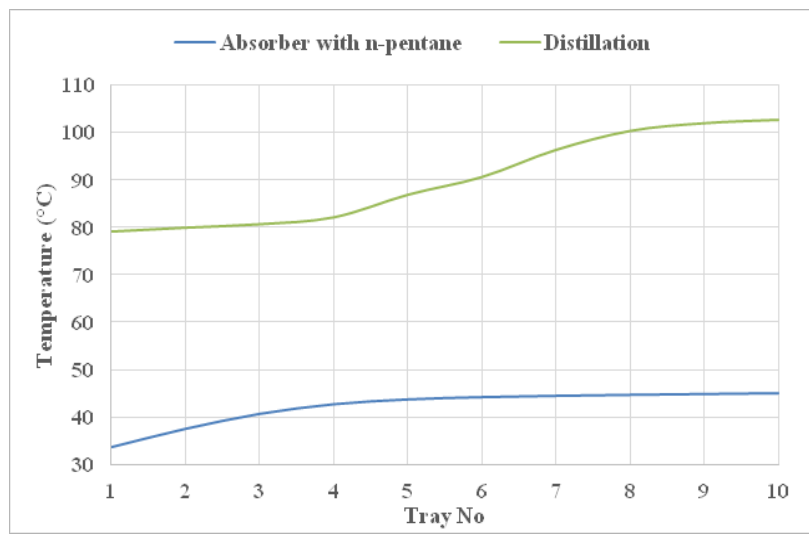

Figure 4 Temperature distribution in new direct contact heat transfer column "absorber".
In spite of maintaining the acid gas loading at $0.48 \mathrm{~mol}$ acid gases/ mol amine, significant savings could be accomplished in the AGR plant. The proposed novel process saves $0.51 \mathrm{~kg}$-cooling water per each $\mathrm{kg}$-circulated amine compared to the conventional scheme, ${ }^{10}$ this saving is due to the elimination of the lean amine trim cooler. Furthermore, the specific electrical saving is $0.024 \mathrm{Kwh}$ per each $\mathrm{kg}$ circulated amine because of eliminating the lean amine air coolers. On the other hand, the AGR contactor and stripper temperature profile is maintained at the same profile as shown in (Figure 5), as the aim of this work is to retrofit the existing AGR plants without affecting the main equipment; Absorber and Stripper.

On the other hand, a parametric study conducted on the novel integrated system to define the effect of n-pentane temperature on the treated water quality and quantity (Table 4). Relation between the n-pentene temperature, treated water characteristics and quantity is reflected in (Figure 6). The obtained results showed that, the treated 
water quality and quantity is directly proportional with the n-pentane temperature. Moreover, when the n-pentane temperature is $40^{\circ} \mathrm{C}$ the ethanol concentration in treated water is about $5.25 \mathrm{wt}$ \%, while when the n-pentane temperature is higher than $65^{\circ} \mathrm{C}$ the ethanol concentration is almost $0 \mathrm{wt} . \%$ and a high quality treated water could be recovered. In other words, increasing the n-pentane temperature enables the n-pentane to absorb more ethanol, hence higher treated water recovery and accordingly, the quality and quantity of treated water increases.

Table 4 Effect of $n$-pentane to diluted draw solution ratio and $n$-pentene temperature

\begin{tabular}{|l|l|l|l|l|}
\hline \multirow{2}{*}{$\begin{array}{l}\text { n-C5 } \\
\text { Temperature } \\
{ }^{\circ} \mathrm{C}\end{array}$} & \multicolumn{3}{|l|}{ Flow Rate $(\mathrm{kg} / \mathrm{hr})$} & $\begin{array}{l}\text { Ethanol Conc in } \\
\text { treated Water } \\
(\mathrm{wt} \%)\end{array}$ \\
\cline { 2 - 5 } & $\mathrm{n}-\mathrm{C5}$ & $\begin{array}{l}\text { Draw } \\
\text { Solution }\end{array}$ & $\begin{array}{l}\text { Treated } \\
\text { Water }\end{array}$ & $2.29 \%$ \\
\hline 40 & 935 & 234 & 211 & $4.46 \%$ \\
\hline 45 & 2044 & 511 & 455 & $3.55 \%$ \\
\hline 50 & 3007 & 752 & 661 & $2.56 \%$ \\
\hline 55 & 3932 & 983 & 852 & $1.50 \%$ \\
\hline 60 & 4820 & 1205 & 1029 & $0.00 \%$ \\
\hline 65 & 5676 & 1400 & 1174 & \\
\hline
\end{tabular}

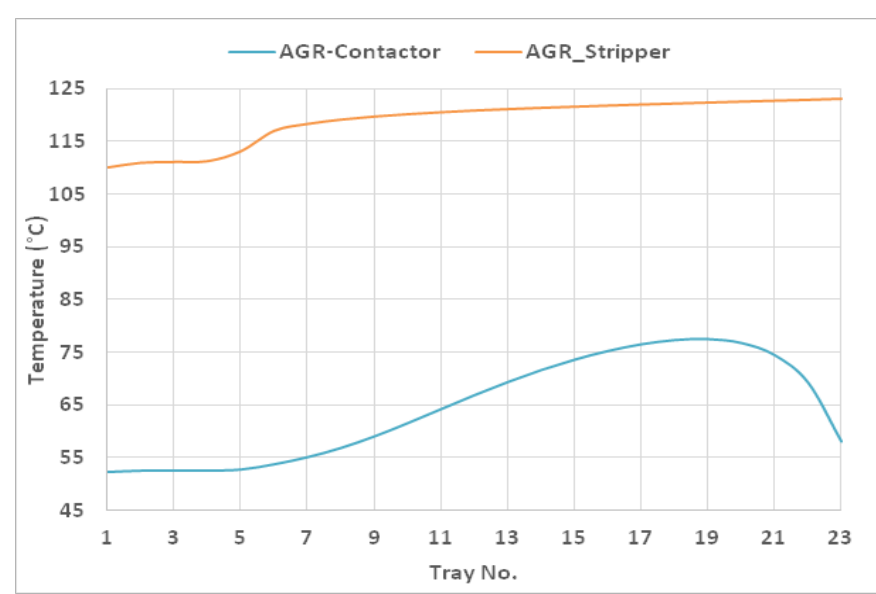

Figure 5 Temperature profile in AGR absorber and stripper.

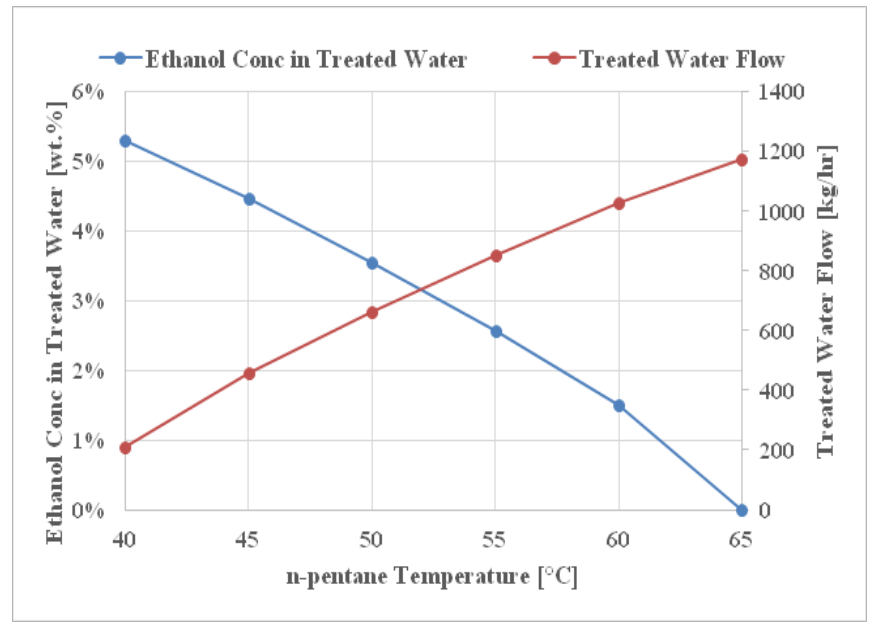

Figure 6 Relation between $n$-pentane temperature and treated water quality and quantity.

\section{Economic analysis}

An economic analysis has been conducted on the novel integration to assess the feasibility of this proposal. Low pressure steam cost, cooling water cost and electricity cost were taken from Turton et al. ${ }^{45}$ while total equipment cost were calculated based on Coulson and Richardson. ${ }^{46}$ Two equipment in AGR plant were eliminated: lean amine air cooler and trim cooler. At the same time, four equipment were eliminated in the DS regeneration section in the FO plant: distillation column, condenser, reboiler and condenser pump.

On the other hand, three equipment have been added: absorber with ten stages (sieve valve or bubble cap trays), economizer and spherical tank. The net capex savings for new plants will be \$9687/MMSCFD while added capex for existing plants is $\$ 6504 /$ MMSCFD. In addition, the net total operating cost savings for both existing and new plants is $\$ 17524 /$ MMSCFD-year and that because of eliminating LP steam, cooling water and reducing electrical consumption due to air coolers, cooling towers and pumping power (Table 5).

Table 5 Techno-economic analysis on 390 MMSCFD gas plant capacity and $345 \mathrm{~m} 3 / \mathrm{hr}$ of treated water

\begin{tabular}{lll}
\hline Acid Gas & Desalination \\
Removal & Forward \\
Plant & Osmosis Plant
\end{tabular}

Capex (Total Equipment Cost)

\begin{tabular}{|c|c|c|c|c|}
\hline & Lean Amine Air Cooler & $\$$ & $2,418,000$ & \\
\hline & $\begin{array}{l}\text { Lean Amine Trim } \\
\text { Cooler }\end{array}$ & $\$$ & $1,088,100$ & \\
\hline \multirow[t]{5}{*}{ Saved } & Distillation Column & $\$$ & & $\mathrm{I}, 8 \mathrm{I} \mathrm{I}, 854$ \\
\hline & Condenser & $\$$ & & 362,371 \\
\hline & Reboiler & $\$$ & & 452,963 \\
\hline & Condenser Pump & $\$$ & & 181,185 \\
\hline & Absorber & $\$$ & & I,630,668 \\
\hline \multirow[t]{2}{*}{ Added } & Economizer & $\$$ & 634,149 & \\
\hline & Tank (pentane) & $\$$ & & 271,778 \\
\hline
\end{tabular}

Opex

\begin{tabular}{|c|c|c|}
\hline Lean Amine Air Cooler & $\$$ \$year & 172,102 \\
\hline Lean Amine Trim & $\$ /$ year & 54,798 \\
\hline
\end{tabular}

Saved

$\begin{array}{ll}\begin{array}{l}\text { Cooling water } \\ \text { pumping Cost }\end{array} & \text { \$/year } \\ \text { Steam Consumption } & \$ / \text { year } \\ \begin{array}{l}\text { Cooling water makeup } \\ \text { in CT }\end{array} & \$ \text { year } \quad 131,462\end{array}$

Summary

New Plants Total Capex Savings

$3,777,878$

Total Operating Cost Savings per plant

\$/year

$6,834,080$
Month 


\section{Conclusions}

This novel process provides a new integration concept of acid gas removal plants with water purification "Forward Osmosis" to eliminate the energy required in cooling the circulated lean amine, ensure smooth operation at summer times, reduce new plants capital cost, reduce electrical and utility consumption and purify the produced and wastewater with minimal thermal energy requirements. The process simulation concluded that, two equipment in AGR plant could be eliminated: lean amine air cooler and trim cooler, which saves $15 \%$ from new AGR plants capex and reduces electrical consumption by more than $20 \%$ for new and existing plants.

This novel process facilitates water-ethanol separation with a projected separation efficiency $>99 \%$ of ethanol from water; a $93.6 \%$ by wt. diluted draw solution could be recovered as a high quality treated water with ethanol concentration less than $3.5 \mathrm{E}-06 \mathrm{ppm}$, wt. and no pentane. It is also concluded that the crucial factors of the DS regenerating process are the mass ratio of light hydrocarbon to diluted DS feed and n-pentane temperature.

A thorough study has been conducted and the results show that to fully absorb all ethanol from water, the ratio must be higher than 3.76 and n-temperature starting from $65^{\circ} \mathrm{C}$. The net capex savings for new AGR unit is $\$ 9687 / \mathrm{MMSCFD}$, while retrofitting capex for existing AGR will cost $\$ 6504 / \mathrm{MMSCFD}$. It conclude that the process is promising and it could help making the water desalination using Forward Osmosis commercially applicable and viable at low capital and operating cost.

\section{References}

1. Administration (US) EI, Office GP. International Energy Outlook 2016 : With Projections to 2040. Government Printing Office; 2016.

2. BP Statistical Review of World Energy 2017.

3. Demirbas A. Hydrogen. Biohydrogen Future Engine Fuel Demands 2009:105-161.

4. Kidnay AJ, Parrish WR, McCartney DG. Fundamentals of Natural Gas Processing. 2nd ed. Boca Raton: CRC Press; 2011.

5. Faiz R, Al-Marzouqi M. Insights on natural gas purification: Simultaneous absorption of $\mathrm{CO} 2$ and $\mathrm{H} 2 \mathrm{~S}$ using membrane contactors. Sep Purif Technol. 2011;76(3):351-361

6. Mokhatab S, Poe WA. Handbook of Natural Gas Transmission and Processing. Gulf professional publishing; 2012.

7. Banat F, Younas O, Didarul I. Energy and exergical dissection of a natural gas sweetening plant using methyldiethanol amine (MDEA) solution. $J$ Nat Gas Sci Eng. 2014;16:1-7.

8. Althuluth MAM, Peters CJ, Berrouk AS, Kroon MC. Separation selectivity of various gases in the ionic liquid 1-ethyl-3-methylimidazolium tris (pentafluoroethyl) trifluorophosphate. In: 2013 AIChE Annual Meeting, November 3-8, 2013, San Francisco, CA, USA.; 2013.

9. Kidnay AJ, Parrish WR. Fundamentals of Natural Gas Processing. CRC press; 2006.

10. Abotaleb A, El-Naas MH, Amhamed A. Enhancing gas loading and reducing energy consumption in acid gas removal systems: A simulation study based on real NGL plant data. J Nat Gas Sci Eng. 2018;55:565-574.

11. Amhamed A, Abotaleb A. Novel AGR-EOR Combination for Treating Extra Natural Gas, Saving Energy, Maximizing Oil Production and CO2 Emissions Mitigation. In: Second EAGE Workshop on Well Injectivity and Productivity in Carbonates.; 2017.
12. Rochelle G, Chen E, Freeman S, Van Wagener D, Xu Q, Voice A. Aqueous piperazine as the new standard for CO2 capture technology. Chem Eng J. 2011;171(3):725-733.

13. Reynolds RR, Kiker RD. Produced water and associated issues. Okla Geol Surv. 2003.

14. Veil JA, Puder MG, Elcock D, Redweik Jr RJ. A White Paper Describing Produced Water from Production of Crude Oil, Natural Gas, and Coal Bed Methane. Argonne National Lab., IL (US); 2004.

15. Alkhudhiri A, Darwish N, Hilal N. Produced water treatment: application of air gap membrane distillation. Desalination. 2013;309:46-51.

16. Drioli E, Ali A, Lee YM, Al-Sharif SF, Al-Beirutty M, Macedonio F. Membrane operations for produced water treatment. Desalination Water Treat. 2016;57(31):14317-14335.

17. Kujawa J, Cerneaux S, Kujawski W. Removal of hazardous volatile organic compounds from water by vacuum pervaporation with hydrophobic ceramic membranes. J Membr Sci. 2015;474:11-19.

18. Du Plessis A. Freshwater Challenges of South Africa and Its Upper Vaal River. Springer; 2017.

19. Younos T, Tulou KE. Overview of desalination techniques. J Contemp Water Res Educ. 2005;132(1):3-10.

20. Al-Anezi AA-H. Performance enhancement of air bubbling and vacuum membrane distillation for water desalination. 2013.

21. Altalyan HN, Jones B, Bradd J, Nghiem LD, Alyazichi YM. Removal of volatile organic compounds (VOCs) from groundwater by reverse osmosis and nanofiltration. J Water Process Eng. 2016;9:9-21.

22. Fritzmann C, Löwenberg J, Wintgens T, Melin T. State-of-the-art of reverse osmosis desalination. Desalination. 2007;216(1-3):1-76.

23. Van der Bruggen B, Lejon L, Vandecasteele C. Reuse, treatment, and discharge of the concentrate of pressure-driven membrane processes. Environ Sci Technol. 2003;37(17):3733-3738.

24. McCutcheon JR, McGinnis RL, Elimelech M. Desalination by ammoniacarbon dioxide forward osmosis: influence of draw and feed solution concentrations on process performance. J Membr Sci. 2006;278(12):114-123.

25. Neff RA. Solvent extractor. April 1964.

26. Batchelder GW. Process for the demineralization of water. March 1965

27. Hough WT. Process for extracting solvent from a solution. October 1970.

28. Yaeli J. Method and apparatus for processing liquid solutions of suspensions particularly useful in the desalination of saline water. March 1992.

29. McGinnis RL, McCutcheon JR, Elimelech M. A novel ammoniacarbon dioxide osmotic heat engine for power generation. J Membr Sci. 2007;305(1-2):13-19.

30. Huang J, Long Q, Xiong S, Shen L, Wang Y. Application of poly (4-styrenesulfonic acid-co-maleic acid) sodium salt as novel draw solute in forward osmosis for dye-containing wastewater treatment. Desalination. 2017;421:40-46. doi:10.1016/j.desal.2017.01.039

31. Zhao D, Wang P, Zhao Q, Chen N, Lu X. Thermoresponsive copolymerbased draw solution for seawater desalination in a combined process of forward osmosis and membrane distillation. Desalination. 2014;348:2632. doi:10.1016/j.desal.2014.06.009

32. Zhao Q, Herng TS, Guo CX, Zhao D, Ding J, Lu X. Thermoresponsive magnetic ionic liquids: synthesis and temperature switchable magnetic separation. RSC Adv. 2016;6(19):15731-15734.

33. Long Q, Shen L, Chen R, Huang J, Xiong S, Wang Y. Synthesis and Application of Organic Phosphonate Salts as Draw Solutes in
Submit your Article | www. ologypress.com/submit-article

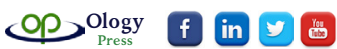


Forward Osmosis for Oil-Water Separation. Environ Sci Technol. 2016;50(21):12022-12029.

34. Long Q, Wang Y. Novel carboxyethyl amine sodium salts as draw solutes with superior forward osmosis performance. AIChE J. 2016;62(4):12261235.

35. Amhamed A, Abotaleb A. Novel Heat Harvesting for Low Energy Draw Solution Regeneration: Simulation Study. J Chem Eng Process Technol. 2017;8(358):17-19.

36. McCormick P, Pellegrino J, Mantovani F, Sarti G. Water, salt, and ethanol diffusion through membranes for water recovery by forward (direct) osmosis processes. J Membr Sci. 2008;325(1):467-478.

37. Arce A, Martinez-Ageitos J, Soto A. VLE for water+ ethanol+ 1-octano mixtures. Experimental measurements and correlations. Fluid Phase Equilibria. 1996;122(1-2):117-129.

38. CRC Handbook of Chemistry and Physics. 74th ed. CRC press; 1993.

39. Vane LM, Alvarez FR, Rosenblum L, Govindaswamy S. Efficient ethanol recovery from yeast fermentation broth with integrated distillationmembrane process. Ind Eng Chem Res. 2012;52(3):1033-1041.
40. Gil ID, Uyazán AM, Aguilar JL, Rodríguez G, Caicedo LA. Separation of ethanol and water by extractive distillation with salt and solvent as entrainer: process simulation. Braz J Chem Eng. 2008;25(1):207-215.

41. Fu J. Simulation of Salt-Containing Extractive Distillation for the System of Ethanol/Water/Ethanediol/KAc. 1. Calculation of the VaporLiquid Equilibrium for the Salt-Containing System. Ind Eng Chem Res. 2004;43(5):1274-1278

42. Sharif A, Mahood H. Alcohol striping Method with Forward Osmosis. UK patent application no GB1403883.0. 2014.

43. Aspen Technology, Inc., Aspen HYSYS online documentation. 2014.

44. Khaia A, Gumah S, Streicher C, Dinh VH. PROCESSING-Successful revamp of QP MDEA unit hikes capacity. Oil Gas J. 2005;103(21):53-58.

45. Turton R, Bailie RC, Whiting WB, Shaeiwitz JA. Analysis, Synthesis and Design of Chemical Processes. Pearson Education; 2008.

46. Coulson JM, Richardson JF. Chemical Engineering. 3rd ed.; 1999.

47. Ahan JA. Characterization of produced water from two offshore oil fields in Qatar. 2014. 